\title{
Pengkanunan Hukum Islam di Indonesia (Kajian dalam Bidang Hukum Keluarga)
}

\author{
Karimatul Ummah
}

\begin{abstract}
The effort of positioning the Islamic Law is very urgent to put into in action in order that the law material is applicable at the Conslitution Court in which finally it becomes absolute competence of Religion Court. Besides that, it is aimed to unify the law toward the certain law , because the judges at the Religion Court would refer to the same law.
\end{abstract}

\section{Pendahuluan}

Syariah dalam arti sempit diartikan dengan Hukum Islam, ${ }^{1}$ bersumber pada wahyu Allah yang memiliki validitas abadi yang secara teoritik aturannya tidak mudah untuk dirubah. Dengan mengutip pendapat para orientalis bahwa dalam syariah terlihat adanya corak khusus yang mencerminkan semangat Islam yang sebenamya, pemyataan Islam yang paling menentukan dan sekaligus merupakan esensi dari Islam itu sendiri, ${ }^{2}$ maka dalam Islam itu sebenarnya sarat dengan pengaturan yang melingkupi setiap aspek kehidupan dan perilaku manusia baik pada tingkat individu maupun pada tingkat sosial kemasyarakatan. Dengan demikian setiap aspek kehidupan dan aspek perilaku duniawi tidak boleh terlepas dari aspek agama.
Meskipun syariah telah memasukkan seluruh aspek kehidupan dan perilaku manusia kedalam cakupannya, tetapi tidak begitu saja dapat dinyatakan sebagai hukum materiil yang mempunyai daya paksa untuk diberlakukan pada lembaga peradilan. Dalam konteks yang demikian maka upaya penuangan nilai-nilai syariah kedalam hukum positif (qanuun) menjadi signifikan untuk dilakukan dalam kerangka menempatkart sifat mengatur, memaksa dan mengikat pada syariah itu. Upaya ini bahkan menjadi keharusan setelah dunia Islam mengenal konsep dan pemikiran hukum di luar islam khususnya dari Barat.

Sebagai upaya awal dalam rangka pengkanunan tersebut, dalam wacana Islam dikenal Majallah al Ahkaam al Adliyyah yang

'Abdul Jamali, Hukum Islam, (Bandung: Mandar Maju, 1992), him.11.

2 Saba Habachy, "introduction" dalam J.N.D. Arderson, Islamic Law in the Modem Wordd (New York: New York University Press, 1959), hlm. x 
merupakan hasil dari usaha mempertemukan pemikiran-pemikiran Islam klasik dengan pemikiran-pemikiran Islam yang telah dipengaruhi konsep dan pemikiran Barat, ${ }^{3}$ bahkan dalam perjalanan sejarah Islam selanjutnya dapat dikatakan bahwa terbitnya Majallah merupakan pengkanunan Hukum Islam pertama yang bersumber pada syariah dengan mendasarkan pada mazhab Hanafi. Upaya awal ini pada tahap selanjutnya diikuti oleh upaya-upaya di bidang hukum keluarga dalam kerangka "membaratkan" Hukum Islam dalam bentuknya bukan dalam substansinya. ${ }^{4}$

Tulisan di bawah ini akan dicoba untuk menguraikan tentang urgensi pengkanunan Hukum Islam di Indonesia bidang Hukum Keluarga, yakni peraturan-peraturan yang oleh kalangan Ahli Hukum Islam diharapkan menjadi rujukan dalam menyelesaikan sengketa menyangkut masalah perkawinan dan kéwarisan serta bagaimana realisasi dari pengkanunan tersebut.

\section{Urgensi Pengkanunan Hukum Islam di Indonesia}

Sebagaimana diuraikan di atas bahwa pengkanunan Hukum Islam dilakukan dalam kerangka:... menempatkan sifăt memaksa,mengikat dan mengatur pada syariah itu. Upaya ini bahkan menjadi keharusan jika dikaitkan dengan keberadaan Peradilan Agama (selanjutnya disingkat PA), sebab adanya hukum positif yang bersumber pada ajaran yang asasi merupakan salah satu syarat dimungkinkannya PA Islam ${ }^{5}$ berdiri di Indonesia.

Bustanul Arifin ${ }^{6}$ mengemukakan bahwa ada tiga pilar sokoguru kekuasaan Kehakiman dalam melaksanakan fungsi peradilan sebagäimana yang diamanatkan Pasal 24 UUD 1945 jo Pasal 10 Undang-Undang Nomor 14 Tahun 1970. Ketiga pilar itu adalah adanya badan peradilan yang terorganisir berdasarkan kekuatan undang-undang, adanya organ pelaksana dan adanya sarana hukúm sebagai rujukan. Salah satu pilar tersebut tidak terpenuhi menyebabkan penyelenggaraan fungsi peradilan tidak berjalan dengan baik. Selanjutnya masing-masing pilar tersebut diuraikan sebagai berikut:

1. Adanya badan peradilan yang terorganisir berdasarkan kekuatan undang-undang. Untuk berdirinya sebuah lembaga peradilan haruslah secara legalistik berdasarkan pada Pasal 10 UU. No. 14 Tahun1970 tentang Pokok-Pokok Kekuasaan Kehakiman yang telah diakui

${ }^{3}$ Samsul Anwar, "Majallah," makalah yang ditulis tanggal 6 November 1986, Hlm.2

-Di India pada masa pemerintahan Raja An Rijib telah memberlakukan ketentuan perundang-undangan yang terkenal dengan nama Fatwa Alamgiri, lihat Bustanul Arifin, KHI dalam Dimensi Hukum Islam dalam Sistem Hukum Nasional (Jakarta: Gema Insani Press, 1996), hlm. 10.

${ }^{5}$ Berdasarkan Sila I dari Pancasila jo Pasal 29 UUD 1945 sebenamya semua Agama resmi yang ada di Indonesia mempunyai peluang untuk mendirikan Peradilan Agama dengan memberlakukan hukum materiil yang bersumber pada ajaran agamanya akan tetapi sejauh ini dilihat dari sejarah dan kenyataan sosial hanya Peradilan Agama Islam lah yang dimungkinkan untukitu.

${ }^{6}$ Bustanul Arifin, Pelembagaan Hukum Islam di Indonesia, Akar Sejarah Hambatan dan Prospeknya (Jakarta: Gema.Insani Press, 1996), hlm.59 
secara resmi sebagai salah satu pelaksana judicial power dalam negara hukum RI. Untuk PA Islam kedudukan kewenangannya atau yurisdiksi dan organisatorisnya lebih lanjut telah diatur dan dijabarkan dalam UU. No. 7 Tahun 1989.

\section{Adanya Organ Pelaksana}

Adanya organ pelaksana ini berfungsi melaksanakan jalannya peradilan, baik menyangkut sumber daya manusianya maupun menyangkut fasilitas penunjang lainnya.

3. Adanya Sarana Hukum sebagai Rujukan Yang dimaksudkan sarana hukum disini adalah adanya hukum materiil yang dijadikan rujukan dan pedoman dalam kompetensi absolutnya. ${ }^{7}$ Yakni hukum yang bernaung di bawah bendera agama dan tidak dapat dikarang-karang oleh manusia melainkan bersumber pada ajaran yang asasi dan primer. ${ }^{8}$

Dalam rangka memenuhi pilar ketiga itulah maka upaya mempositifkan Hukum Islam menjadi urgen untuk dilakukan agar materi hukumnya dapat diaplikasikan sebagai hukum materiil pada lembaga peradilan yang pada akhimya menjadi kompetensi absolut PA. Adanya hukum positif yang akan diberlakukan sebagai hukum materiil di PA juga dimaksudkan agar terjadi kesatuan hukum yang pada akhirnya terwujud kepastian hukum mengingat hakim-hakim di PA senantiasa akan merujuk kepada satu aturan hukum yang sama.

Sejalan dengan pentingnya adà aturanaturan hukum yang dapat dijadikan sebagai rujukan hakim dalam memeriksa, memutus dan mienyelesaikan perkara-perkara di bidang hukum keluarga pada PA tersebut memunculkan gagasan untuk membuat proyek pembangunan Hukum Isiam melalui yurisprudensi. Gagasan ini dikemukakan oleh Ketua Muda Mahkamah Agung Urusan Lingkungan Peradilan Agama. Gagasar tersebut selengkapnya didasari adanya pertimbangan sebagai berikut: ${ }^{9}$ (a)Untuk dapat berlakunya Hukum Islam di Indonesia. harus ada'antara lain hukum yang jelas dan dapat dilaksanakan oleh aparat penegak hukum maupun masyarakat. (b) Persepsi yang tidak seragam tentang syariah akan dan sudah menyebabkan hal-hal: (1) ketidakseragaman dalam menentukan apa yang disebut dengan Hukum Islam (maa anzalallahu); (2) tidak adanya kejelasan, bagaimana menjalankan syariat (tanfidziyyah); dan (3) akibat jauh tidak adanya kemampuan untuk menggunakan jalan dan alat yang tersedia dalam UUD 1945 dan perundang-undangan lainnya. (c) Dalam sejarah Islam pernah di beberapa negara Hukum Islam diberlakukan sebagai perundang-undangan negara seperti di India dan di Turki Utsmani.

\footnotetext{
${ }^{7}$ Kompetensi absolut dari pengadilan adalah kewenangan yang diberikan oleh undang-undang kepada pengadilan untuk memeriksa, mengadili dan menyelesaikan suatu perkara atas $\mathrm{d}$..zar materi perkaranya.Lihat Roihan A. Rasyid, Hukum Acara Peradilan Agama (Jakarta: Rajawali Press, 1990), him. 27.

${ }^{8}$ Moh. Mahfud, "Peluang Konstitusional bagi PA," dalam Moh. Mahfud Drk (ed) PA dan Kompilasi Hukum Islam dalam Tata Hukum Indonesia (Yogyakarta: UII Press, 1993), hlm.22

${ }^{9}$ Bustanul Arifin, op. cit.
} 
Sketsa Historis: Realisasi Pengkanunan Hukum Islam di Indonesia

Sejak aẃwal kehadiran islam, upaya mempositifkan Hukum Islam di indonesia sebagai hukum yang keberadaannya diakui sebagai hukum materiil sudah pernah dilakukan, karena pada masa itu Hukum Islam sudah diterapkan dan dikembangkan di lingkungan masyarakat Islam. Hamka menyebutkan sebagai contoh adalah hasil karya Ahli Hukum Islam di Indonesia seperti Siraat al Mustaqiim karya Nuruddin ar Raniri (1628), Sabiil al Muhtadiin karya Syeh M. Arsyad al Banjari dan Mirrat at Tullab karya Abdur Rauf Singkel, meskipun semuanya masih bercorak pembahasan figh yang berorientasi pada ajaran mazhab Syafi'i, ${ }^{10}$ bahkan menurut Hamka kitab yang ditulis ar Raniri tersebut merupakan kitab fiqh pertama yang disebarkan di Indonesia meskipun penyebarannya tidak dilakukan oleh lembaga formal yang dibentuk secara khusus untuk tujuan tersebut." Hal ini dikarenakan fungsionaris yang. melaksanakan Hukum Islam berada di tangan golongan Ulama'.

Keadaan demikian disebabkan, setelah Islam memperoleh tempat yang kokoh dalam masyarakat kota perdagangan pesisir pantai terjadi peralihan peran dari kaum saudagar ke tangan para Ulama". Selanjutnya para Ulama bertindak sebagai fungsionaris yang menyelesaikan sengketa di antara sesama pemeluk Islam. Dalam keadaan yang demikian menurut Saefudin Zuhri'? melahirkan peradilan informal yang disebut dengan "Tahkim" sebagai wadah, sarana dan tempat masyarakat menyelesaikan persengketaan perkawinan, kewarisan, hibah dan wasiat.

Pendapat tersebut didukung pula oleh Zaini Ahmad Noeh ${ }^{13}$ yang mengatakan bahwa kelahiran "tahkim" yang secara informal itu tumbuh dan berkembang untuk menampung kebutuhan masyarakat dan atas kehendak masyarakat dalam menyelesaikan perkaraperkara tersebut. Dengan demikian meskipun "tahkim" lahir dan tumbuh bukan atas bentukan penguasa dan merupakan wadah informal dalam menyelesaikan perkara, akan tetapi putusannya diikuti masyarakat sebagai putusan yang bersifat formal. Hal tersebut dapat dilihat setiap kali terjadi masalah perkawinan ataupun kewarisan selalu mencari penyelesaian melalui tahkim dengan mencari dasar rujukan hukum yang tertuang dalam kitab figh tersebut dan merupakan hasil abstraksi yang berorientasi pada mazhab Syafi'. Keadaan demikian bediangsung terus sampai lahirnya pusat-pusat kekuasaan kesultanan kerajaan-kerajaan Islam.

Pada masa pemerintahan VOC upaya mempositifkan Hukum Islam juga dilakukan

${ }^{10}$ Hamka, Mazhab Syafi.i di Indonesia antara fakta dan khayal Tuanku Rao (Jakarta: Bulan Bintang. 1974), hlm.74 seperti yang dikutip oleh Yahya Harahap, "Materi Kompilasi Hukum Islam," makalah pada Seminar Peradilan Agama dan Kompilasi Hukum Islam, Yogyakarta: 1993, hlm.3

"lbid. HIm.5

12 Saifudin Zuhri, Sejarah Kebangkitan Islam dan Perkembangannya di indonesia (Bandung: al Ma'arif, 1979), him. 204

${ }^{13}$ Zaini Ahmad Noeh, Sebuah Perspektif Sejarah Lembaga Isiam di Indonesia (Bandung: al Ma'arif, 1980), hlm. 9. 
sebagai wujud kesadaran Belanda akan adanya kenyataan bahwa orang-orang pribumi memberlakukan hukum agamanya. Belanda mewujudkannya dalam bentuk kumpulan materi hukum untuk dijadikan pedoman formal oleh pejabat dalam menyelesaikan urusan hukum rakyat pribumi. Kumpulan materi hukum yang dimaksud adalah:

1. Compendium Freijer disusun oleh D.W Freijer berisi materi hukum perkawinan dan kewarisan Islam yang tertuang dalam Resolutie der Indische Regering tanggal 25 Mei 1760 . Materi hukum yang tertuang dalam Compendium Freijer tersebut merupakan pengkanunan hukum Islam pertama pada masa pemerintahan VOC.

2. Tjirebonsche rechtboek atau yang dikenal dengan Pepakem Cirebon merupakan kitab hukum yang berisi hukum Jawa yang tua berlaku untuk wilayah Pengadilan Cirebon. Kitab ini disusun atas usul Mr. P.C. Hasselaar.

3. Compendium der Vomaamste Javaansche Wetten nauwkeurig getrokken uit het Mohammedaansche Wetboek Moegharraer, dibuat untuk kepentingan landraad Semarang. Kitab hukum ini berisi tentang hukum Jawa yang disaring dari kitab Hukum Islam Muharrar karya ar Rafi'i, di dalamnya berisi kumpulan Hukum Tuhan, Hukum Alam, dan Hukum Anak Negeri. Kitab ini dipakai untuk memutus perkara perdata dan pidana di kalangan rakyat daerah.

4. Compendium Indlandsche Wetten bij de hoven van Bone en Goa, dibuat untuk daerah Makassar atas prakarsa B.J.D Clootwijke.

Compendium Freijer yang merupakan pengkanunan Hukum Keluarga pertama. itu pada akhirnya diperbaharui dengan Besluit van den Commissaris Generaal tanggal 3 Agustus 1828 termuat dalam Stb. 1828 nomor 55, dan pada akhirnya dicabut secara berangsurangsur dimulai dengan materi hukum perkawinan pada abad ke-19, sedangkan hukum kewarisan baru dicabut pada 1913 dengan Koninklijke Besluit pada tanggal 17 Pebruari 1913 temuan dalam Stb. 1913 nomor 354. Dengan demikian tamatlah riwayat pengkanunan hukum perkawinan dan kewarisan Islam yang berdiri sendiri menjadi hukum positif dan selanjutnya keberadaannya hanya menumpang pada Pasal 131 (2) b Indische Staatsregeling (IS) yang merupakan kelanjutan dari Pasal 75 Regerings Reglement (RR) 1954.

Pada masa setelah Indonesia merdeka pengkanunan hukum Islam dilakukan ketika pada tanggal 2 Januari 1974 diundangkan UU No.1 Tahun 1974 tentang Pokok-pokok Perkawinan dengan Peraturan Pelaksanaannya yang tertuang dalam PP No.9 Tahun 1975 yang berlaku untuk seluruh wilayah Indonesia. Undang-undang ini memang tidak secara khusus ditujukan untuk umat Islam di Indonesia, akan tetapi jika dilihat dari materi hukum yang termuat di dalamnya dapat dikatakan bahwa undang-undang ini merupakan tonggak sejarah keberhasilan umat Islam untuk menuangkan nilai-nilai syariah di bidang perkawinan. Hal ini dapat dilihat dari beberapa asas perkawinan Islam yang terkandung di dalamnya, seperti asas sukarela, partisipasi keluarga, perceraian dipersulit, poligami dibatasi secara ketat, kematangan calon mempelai dan upaya memperbaiki derajat wanita. Undang-undang ini pula yang dijadikan sebagai hukum materiil 
yang menjadi yurisdiksi PA ketika memeriksa, mengadili dan memutus perkara-perkara yang menyangkut perkawinan antara orang-orang yang beragama Islam.

Peraturan perundang-undangan tersebut selain merupakan refleksi dari eksistensi PA ${ }^{14}$ juga merupakan langkah baru dalam menjadikan sebagian hukum Islam menjadi hukum tertulis, meskipun harus diakui bahwa masih banyak bagian-bagian dari hukum perkawinan Islam yang menjadi bagian dari kewenangan PA itu masih berada di luar hukum yang tertulis tersebut. ${ }^{15}$

Di bidang kewarisan keinginan untuk melakukan pengkanunan tersebut pemah pula tercetuskan ketika muncul gagasan untuk merumuskan hukum waris nasional sebagaimana pada hukum perkawinan. Upaya tersebut dalam kenyataannya terganjal adanya perdebatan di antara umat Islam sendiri menyangkut beberapa materi dari hukum waris, antara lain: ${ }^{16}$

1. Hapusnya hak waris karena adanya perbedaan agama antara pewaris dengan ahli waris.

Ahli waris yang berbeda agama dengan pewaris terhalang untuk mendapatkan warisan. Alternatif penyelesaiannya ada yang menyetujui dilakukan pengalihan harta dengan cara hibah wasiat, tetapi sebagian lagi tetap berpedapat bahwa hak mendapatkan warisan tersebut gugur karena adanya perbedaan agama antara pewaris dengan ahli waris berdasarkan hadits Nabi yang diriwayatkan oleh Imam Empat bahwa tidak ada hak mewarisi antara orang Isiam dengan orang kafir dan sebaliknya tidak ada hak mewarisi antara orang kafir dengan orang Islam. Dengan demikian adanya perbedaan agama telah menyebabkan hijab untuk saling mewarisi.

2. Bagian anak laki-laki dan anak perempuan.

Mengenai besarnya bagian antara anak laki-laki dengan anak perempuan, ada yang menghendaki 1: 2 dalam arti anak laki-laki mendapatkan dua kali bagian anak perempuan sebagaimana yang diamanatkan dalam al-Quran. Di pihak lain ada pula yang menghendaki bahwa bagian anak laki-laki dengan anak perempuan adalah sama atas dasar keadilan. Alasan dari pendapat yang kedua ini adalah bahwa yang harus diutamakan adalah bahwa ketika Allah menetapkan bagian laki-laki dua kali bagian dari anak perempuan dimaksudkan adanya keadilan karena laki-laki mempunyai kewajiban memberikan nafkah kepada istrinya. Dengan demikian nilai keadilan yang harus diutamakan dan bukan pada patokan angka $1: 2$. Jika di masa sekarang

\footnotetext{
"Abdul Gani Abduillah, Penganfar Komilasi Hukumislam dalam Tata Hukum Indonesia (Jakarta:Gema insani Press, 1994), hilm. 36

is Zarkowi Soejoeti, Sejarah Penyusunan Komilasi Hukum Islam dilndonesia dalam Moh.Mahfud MD dkk (ed) Pertadilan Agama dan Komilasi Hukum/slamdalam Tata Hukumindonesia (Yogyakarta: Ull Press, 1993), hlm.46
}

${ }^{16}$ Kesimpulan Simposium Hukum Waris Nasional di Jakarta tanggal 10 - 12 Pebruari 1983 
patokan angka 1:2 sebagaimana tersebut di atas dirasakan kurang mencerminkan keadilan maka ketentuan tersebut boleh disimpangi.

3. Status dan Kedudukan anak angkat dalam masalah kewarisan.

Mengenai status dan kedudukan anak angkat semua sepakat bahwa anak angkat tidak berhak mendapatkan warisan dari orang tua angkatnya. Akan tetapi perbedaan pendapat terjadi manakala anak angkat yang dimaksudkan ternyata mengasihi dan merawat orang tua angkatnya melebihi anak kandung. Dalam hal demikian maka untuk keadilan dan kemaslahatan terhadap anak angkat yang dimaksudkan diberikan bagian atas dasar wasiat wajibah. Penetapan hukum yang demikian inilah yang memicu adanya perbedaan pendapat, sebab di satu sisi ada yang menyetujui dengan alasan kemaslahatan dan keadilan namun di sisi yang lain menolak dengan alasan tidak adanya hubungan nasab antara anak angkat dengan orang tua angkatnya.

Pengkanunan hukum keluarga yang meliputi bidang hukum perkawinan dan kewarisan baru benar-benar menjadi kenyataan dengan lahimya Kompilasi Hukum Islam (selanjutnya disingkat $\mathrm{KHI}$ ) yang penyebarluasannya dituangkan dalam bentuk Inpres No. 1 Tahun 1991. KHI ini berisi tiga materi hukum yakni hukum perkawinan, hukum kewarisan dan hukum perwakafan.

\section{KHI sebagai Produk Pengkanunan} Hukum Islam di Indomesi-

Dengan memperhatikan uraian yang telah dibahas di depan dapatlah diketahui bahwa kebutuhan untuk menyusun hukum positif yang akan diberlakukan sebagai hukum materiil di PA lebih banyak dikaitkan dengan fungsi PA. Asumsi ini didukung oleh kenyataan historis bahwa kebutuhan akan adanya hukum positif merupakan salah satu pilar didirikannya lembaga Peradilan Agama di Indonesia, sekaligus juga sebagai upaya untuk memperoleh kesatuan hukum dalam memeriksa dan memutus perkara dilingkungan PA, yang pada akhimya akan tercapai kepastian hukum pula. Hal yang demikian ini sejalan dengan tujuan disusunnya KHI sebagai berikut:

1. Melengkapi Pilar Peradilan Agama

Sebagaimana diuraikan dalar! pembahasan terdahulu untuk mendirikan lembaga PA di Indonesia haruslah memenuhi unsur-unsur yang terdiri dari:

a. Adanya badan yang terorganisir berdasarkan kekuatan undangundang. Kedudukan kewenangan dan yurisdiksi PA serta organisatorisnya diatur dan dijabarkan dalam UU. No.7 Tahun 1989.

b. Adanya organ pelaksana yang berfungsi melaksanakan jalannya peradilan. Hal yang demikian telah lama dimiliki oleh PA dan terus mengaiami perkembangan dari waktu ke waktu, meskipun harus diakui masih terdapat kelemahan dalam pelaksanaannya.

c. Adanya sarana hukum sebagai rujukan, sehingga terjadi kesatuan dan kepastian hukum.

2. Menyamakan persepsi penerapan tiukum Dengan lahiinya $\mathrm{KHI}$ diharapkan dapat menjadi jelas dan pasti adanya nilai-nilai 
tata hukum Islam terutama di bidang hukum perkawinan dan kewarisan yang dapat menjadi rujukan bagi hakim PA dalam memutus setiap perkara yang diajukan padanya, sehingga para hakim tidak lagi dibenarkan menjatuhkan putusan yang berdisparitas sebagai akibat adanya perbedaan dalam memahami, menerapkan dan menginterpretasikan ketentuan hukum yang ada dalam kitab figh.

Dengan adanya persamaan persepsi, penerapan hukum ini para hakim diharapkan bisa menegakkan hukum dan menjamin adanya kepastian hukum yang seragam tanpa mengurangi kemungkinan terjadinya putusan yang bercorak variabel selama tetap proporsional secara kasuistik.

3. Mempercepat proses taqribi bainal ummah

Tujuan lain yang menjadi sasaran disusunnya $\mathrm{KHI}$ adalah mempercepat proses taqribi bainal ummah, karena dengan adanya $\mathrm{KHI}$ ini dapat diharapkan menjadi saranake arah memperkecil pertentangan dan perbantahan khilafiyah yang selama ini sering terjadi.

4. Menjauhkan faham privat affair

Dari pengamatan yang ada selama ini penghayatan dan kesadaran masyarakat Islam banyak menilai bahwa persoalan yang mengandung nilai-nilai hukum Islam selalu dianggap sebagai urusan pribadi, seperti tindakan perkawinan, perceraian, wasiat, dan hibah. Akibat adanya faham yang denikian ini tindakan yang dilakukan masyarakat tersebut seakan tidak perlu campur tangan orang lain, dalam hal ini penguasa. Timbullah anggapan bahwa jika seseorang akan bercerai sematamata hanyalah urusan seseorang dengan Tuhannya. Pandangan yang demikian ini muncul sebagai akibat ketidak mampuan masyarakat Islam dalam membedakan huququllah atau masalah ubudiyah dengan urusan yang termasuk huququl 'ibad atau mu'amalah.

Kebutuhan akan adanya hukum positif sebagaimana tersebut di atas tidak pernah hilang bahkan terus berkembang sejalan dengan perkembangan badan peradilannya. Hal ini terbukti ketika dikeluarkannya Peraturan Pemerintah No. 45 Tahun 1957 tentang Pembentukan Pengadilan Agama atau Mahkamah Syar'iyyah di luar Jawa dan Madura, Kepala Biro Peradilan Agama Departemen Agama segera mengeluarkan Surat Edaran nomor B/1/735 tanggal 18 Pebruari 1958 yang intinya menganjurkan kepada kakim-hakim PA untuk menggunaan 13 kitab figh sebagai pedoman dalam memeriksa dan memutus perkara yang diajukan padanya. Anjuran penggunaan 13 Kitab figh tersebut dimaksudkan agar putusan yang dihasilkan oleh hakim PA tidak lagi berdisparitas terhadap masalah yang sama. Ketigabelas kitab figh yang dimaksudkan adalah: (1) al Bajuri; (2) Fath al Mu'iin; (3) Syarqawi 'ala at Thrir, (4) al Mahalli; (5) Fath al Wahhab; (6) Tuhfat; (7) Targhib al Musytaq; (8) Qawanin asy Syar'iyyah; (9) Qawanin asy Syar'iyyah li as Sayyid Sadaqah Dahlan; (10) Syamsuri fi al Fara'id; (11) Bughyat al Musytarsyidin; (12) al Fiqhu 'ala al Mazahib al Arba'ah; (13)Mughni al Muhtaj.

Dengan ditunjuknya 13 kitab fiqh sebagai rujukan dalam pengambil-putusan oleh hakim PA tersebut, langkah ke arah unifikasi hukum 
memang sedikit terpenuhi, meskipun harus diakui bahwa dari segi kepastian hukum masih dipertanyakan sebab 13 kitab fiqh yang dimaksudkan bukan berasal dari satu mazhab. Dengan demikian jika hakim yang memeriksa dan memutus perkara berpegang teguh pada satu mazhab akan berpaling dari kitab figh yang bukan dari mazhab yang diyakini. Akibatnya putusan hakim satu dengan lainnya akan berbeda. Unifikasi di bidang hukum perkawinan semakin nampak nyata setelah dikeluarkannya UU No.1 Tahun 1974 tentang Perkawinan beserta peraturan pelaksananya yang termuat dalam PP No. 9 Taḥun 1975 sebagaimana tersebut di atas.

Dalam perkembangan selanjutnya meskipun telah ditetapkan unfuk menggunakan 13 kitab fiqh yang dimaksudkan akan tetapi sifat unifikatif dalam putusan PA belum juga terwujud dengan baik. Penyebabnya banyak para hakim PA dalam mengaplikasikan dan menginterpretasikan ketentuan figh yang menjadi rujukan tersebut dalam suatu putusan tidak bisa dilepaskan dari latar belakang mazhab yang dianutnya, akibatnya terdapat putusan PA yang berdisparitas antara satu dengan yang lain terhadap perkara yang sama. Jika hakim yang memeriksa dan memutus perkara bermazhab Hanafi maka putusannya akan sangat dipengaruhi dengan dasar dan pertimbangan hukum yang ada dalam mazhab Hanafi dan sebagainya. Dengan demikian para hakim yang kokoh berlatar belakang mazhab tertentu selalu bersikap otoriter dan doktriner secara deskriptif dan tidak mau beranjak sedikitpun dari mazhab yang diikutinya. ${ }^{17}$
Melihat uraian di atas, maka dapatlah difahami jika upaya pengkanunan Hukum:Islam bidang hukum Perkawinan dan Kewarisan merupakan upaya yang diharapkan segera terwujud agar kesatuan dan kepastian hukum segera terpenuhi. Keinginan yang -demikian ini terealisir dalam bentuk Kompilasi Hukum Islam.

Dengan adanya KHI sebagai hukum positif dan unifikatif diharapkan pemahamanpemahaman yang berbeda dalam menerapkan Hukum Islam sebagaimana tersebut di atas dapat dijauhkan dengan mulc: menerapkan materi hukum yang terkandung di dalamnya sebagai hukum perdata Islam yang resmi dan dapat dipaksakan penerapannya oleh alat kekuasaan negara terutama oleh badan peradilan agama.

\section{Simpulan}

Berdasarkan uraian di atas dapat disimpulkan bahwa pengkanunan Hukum Islam di Indonesia menjadi signifikan untuk dilakukan dalam kerangka menempatkan sifat memaksa dan mengatur daiam Hukum Islam itu yang pada akhirnya dijadikan sebagai kompetensi absolut dari Peradilan Agama. Disamping itu juga dimaksudkan agar terjadi kesatuan hukum yang menjadi rujukan hakim di Pengadilan Agama dan pada akhirnya menimbulkan kepastian hukum. Pengksnunan Hukum Islam bidang hukum keluarga terwujud dengan disusunnya Kompilasi Hukum Islam (KHI) yang penyebarannya dilakukan dengan Inpres No. 1 Tahun 4991.

"Zarkowi Soeyoeti, "Sejarah penyusunan Kompilasi Hukum Islam di Indonesia," dalam Moh. Mahfud dkk (ed), op.cit 


\section{Daftar Pustaka}

Abdullah, Abdul Gani, Pengantar Komilasi Hukum Islam dalam Tata Hukum Indonesia, Jakarta: Gema insani Press, 1994.

Anderson, J.N.D., Islamic Law in the Modem World, New York: New York University Press, 1959.

Anwar, Samsul, Majallah, makalah yang ditulis tanggal 6 November 1986.

Arifin, Bustanul, Pelembagaan Hukum Islam di Indonesia, Akar Sejarah Hambatan dan Prospeknya, Jakarta: Gema Insani Press, 1996.

Hamka, Mazhab Syafi'i di Indonesia antara fakta dan khayal Tuanku Rao, Jakarta: Bulan Bintang, 1974.

Harahap, Yahya, "Materi Kompilasi Hukum Islam," makalah pada Seminar Peradilan
Agama dan Kompilasi Hukum Islam, Yogyakarta: 1993.

Jamali, Abdul, Hukum Islam, Bandung: Mandar Maju, 1992.

Kesimpulan Simposium Hukum Waris

-- Nasional di Jäkarta tanggal 10 - 12 Pebruari 1983

Mahfud, Moh. Dkk (ed), PA dan Kompilasi Hukum Islam dalam Tata Hukum Indonesia, Yogyakarta: Ull Press, 1993.

Noeh, Zaini Ahmad, Sebuah Perspektif Sejarah Lembaga Islam dindonesia, Bandung: al Ma'arif, 1980.

Rasyid, Roihan A., Hukum Acara Peradilan Agama, Jakarta: Rajawali Press, 1990.

Zuhri, Saifudin, Sejarah Kebangkitan Islam dan Perkembangannya di Indonesia, Bandung: al Ma'arif, 1979.

808080 